\title{
Contribution of zooplankton as a biological element in the assessment of reservoir water quality
}

\author{
Rafaela Almeida1, Nuno E Formigo ${ }^{1,2,}$, Isabel Sousa-Pinto ${ }^{1,2}$, and Sara C Antunes, $1,2, *$ \\ ${ }^{1}$ Department of Biology, Faculty of Sciences, University of Porto, Rua do Campo Alegre s/n, 4169-007, Porto, \\ Portugal. \\ 2 CIIMAR/CIMAR, Interdisciplinary Centre of Marine and Environmental Research, Novo Edifício do Terminal \\ de Cruzeiros do Porto de Leixões, Avenida General Norton de Matos, s/n, 4450-208 Matosinhos, Portugal. \\ * Corresponding author: scantunes@fc.up.pt
}

Received: 05/11/18 Accepted: $14 / 04 / 19$

\begin{abstract}
Contribution of zooplankton as a biological element in the assessment of reservoir water quality

European water policies aim to achieve a good ecological status in all water bodies. The Water Framework Directive (WFD) defined a group of biological elements to assess water quality. In reservoirs and lakes, phytoplankton is the only biological element used for water quality evaluation. However, zooplankton is an important link in the trophic web, since it is able to control the phytoplankton community and was already described as a good bioindicator, with high sensitivity to different environmental stresses. The main goal of this work is to demonstrate the ability of zooplankton communities to be used in the evaluation of water quality in reservoirs. A group of four reservoirs in the north of Portugal (Paradela, Alto Cávado, Alto Rabagão, and Venda Nova) were sampled every three months, during one year, to assess the water quality. Physical and chemical parameters, as well as phytoplankton communities, were studied according to the metrics proposed by the WFD for this typology of water bodies. Additionally, zooplankton communities were also sampled in each reservoir, to understand if their seasonal dynamics are influenced by alterations of the water quality in the reservoirs. Results show that the reservoirs present a good ecological potential, according to WFD reference values for physical and chemical parameters and phytoplankton communities, with occasional drops to moderate ecological potential due to variations in the dissolved $\mathrm{O}_{2}$ and total phosphorus values. The results observed in the dynamics of zooplankton communities show that this biological element is sensitive to changes in the reservoirs and provides a more detailed image of the state of the ecosystem. Zooplankton communities responded to alterations in the water level in the reservoir, to shifts in the trophic status and in the water quality, both at the taxonomic level and on a functional perspective. Therefore, the metrics proposed by WFD to evaluate water quality in reservoirs seem to be insufficient to understand all the alterations that occur in these aquatic ecosystems.
\end{abstract}

Key words: physical and chemical parameters, phytoplankton, zooplankton, functional groups, water quality, lentic freshwater ecosystems

\section{RESUMEN}

La contribución del zooplankton como elemento biológico en la evaluación de la calidad del agua de los embalses

Las políticas europeas sobre el agua tienen como objetivo lograr un buen estado ecológico en todos los cuerpos de agua. La Directiva Marco del Agua (DMA) definió un grupo de elementos biológicos para evaluar la calidad del agua. En embalses y lagos, el fitoplancton es el único elemento biológico utilizado para la evaluación de la calidad del agua. Sin embargo, el zooplancton es un enlace importante en la red trófica, y a que es capaz de controlar la comunidad de fitoplancton y ya se describió como un buen bioindicador, con alta sensibilidad a diferentes estreses ambientales. El objetivo principal de este trabajo es demostrar la capacidad de las comunidades de zooplancton para ser utilizadas en la evaluación de la calidad del agua en los embalses. Se tomaron muestras trimestrales de un grupo de varios embalses en el norte de Portugal (Paradela, Alto Cávado, Alto Rabagão y Venda Nova) durante un año, para evaluar la calidad del agua. Los parámetros físicos y químicos, así como las comunidades de fitoplancton, se estudiaron de acuerdo con las métricas propuestas por la DMA para esta tipología de 
cuerpos de agua. Además, se muestrearon las comunidades de zooplancton en cada embalse, para comprender si su dinámica estacional está influenciada por alteraciones de la calidad del agua. Los resultados muestran que los embalses presentan un buen potencial ecológico, de acuerdo con los valores de referencia de la DMA para los parámetros físicos y químicos, así como para las comunidades de fitoplancton, con caídas ocasionales del potencial ecológico para una calidad moderada, debido a las variaciones en los valores de $\mathrm{O}_{2}$ disuelto y fósforo total. Los resultados observados en la dinámica de las comunidades de zooplancton muestran que este elemento biológico es sensible a alteraciones en los embalses y proporciona una imagen más detallada del estado del ecosistema. Las comunidades de zooplancton respondieron a alteraciones en el nivel del agua en el embalse, a los cambios en el estado trófico y en la calidad del agua, tanto a nivel taxonómico como desde una perspectiva funcional. Por lo tanto, las métricas propuestas por WFD para evaluar la calidad del agua de embalses, parecen ser insuficientes para comprender todas las alteraciones que ocurren en estos ecosistemas lénticos.

Palabras clave: parámetros físicos y químicos, fitoplancton, zooplancton, grupos funcionales, calidad del agua, ecosistemas lenticos

\section{INTRODUCTION}

The alteration and degradation of aquatic ecosystems worldwide by abusive human exploitation demanded an urgent creation of tools to analyze and monitor the present status of ecosystems and, also, predict future alterations. The European Water Framework Directive (WFD) is the most important directive in the European Union concerning in-land aquatic resources quality management and protection (Martinez-Haro et al., 2015). WFD proposes the use of stipulated criteria of physical, chemical, biological and hydromorphological parameters to assess the ecological status of a water body by providing guidelines for each parameter. Using reference values stated by the directive for each country, the water bodies are classified under five classes of quality: high, good, moderate, poor and bad (WFD, 2000).

Damming is a particularly important human impact on river ecosystems (Molles \& Cahill, 1999). Dams are constructions of great importance to our societal needs (Herschy, 2012), however, they induce a strong modification on the rivers natural course and entail major consequences to aquatic biota. On the other hand, reservoirs are artificial lentic waterbodies, formed upstream as a consequence of dam construction (INAG, 2009). These artificial ecosystems are similar to natural lakes in various aspects, such as water storage and low flow. However, they differ in other aspects as geomorphometry, annual and inter-annual storage variability, management options and catchment area (INAG, 2009), given that they have much larger fluctuations in the water level than a natural lake and, frequently, dams have a bottom outlet system that releases sediments and water at higher depth, a phenomenon that normally does not occur in natural ecosystems (McCartney et al., 1999). This switch from a lotic into a lentic system may compromise the integrity of the aquatic ecosystem, altering the water quality, aquatic food webs, seasonal variations of river flow and sediment transport (McCartney et al., 1999). The impact of a reservoir on the aquatic ecosystem is significantly dependent on human activities within the catchment area, such as recreational activities, industry, agriculture and animal farming. These activities can increase the load of chemicals and nutrients (namely, phosphorus and nitrogen), with an increase in the degradation of the water quality, affecting the aquatic communities established in the reservoir, and eventually causing alterations in downstream ecosystems (McCartney et al., 1999).

Concerning the biological quality elements for reservoirs, WFD proposes only the evaluation of phytoplankton (main primary producer in aquatic ecosystems) to assess water quality of these highly modified water bodies (WFD, 2000; INAG, 2009). Indeed, consumers such as fish and zooplankton are not included in WFD for quality classification of this water body typology. Zooplankton represents the group of small heterotrophic organisms that live drifting in lentic freshwater ecosystems, playing an important role in the food webs with energy transfer to high trophic levels of these ecosystems. As primary consumers, these communities represent an important link in the flow of matter and energy 
between phytoplanktonic producers and planktivorous fish (Abrantes et al., 2006; Jensen et al., 2013). They are also responsible for the water body capacity of self-purification since they feed on suspended particles (An et al., 2012; Li et al., 2014). However, zooplankton community composition and abundance are highly dependent on various factors, including competition and predation (Kehayias et al., 2008), and pH changes or food availability (Allen et al., 1999). Indeed, several authors have demonstrated that zooplankton community is strongly influenced by both bottom-up and top-down processes, being strongly dependent on the nutrient availability and abundance of phytoplankton, and also on predation from fish and macroinvertebrates (Abrantes et al., 2006). The body sizes of the organisms, as well as the species composition, are a reflex of the biological pressures on the zooplanktonic community (Brooks \& Dodson, 1965; An et al., 2012) and also provide an image of the functional properties of waterbodies and their fluctuation (Castro et al., 2005; Jensen et al., 2013; Azevêdo et al., 2015). Functional traits have been discussed amongst several authors as valuable indicators of ecosystem stability and functioning (Barnett et al., 2007; Jensen et al., 2013). Going a step further from the taxonomic analysis of communities, with a functional approach it is possible to correlate the processes in community responses to alterations on their environment (Chen et al., 2010). In the case of zooplankton, body size and feeding apparatus are considered key traits that can be related to the trophic state of water bodies (Jensen et al., 2013). Based on the above, in the last years, many authors have discussed the possibility to include the zooplankton community in the WFD as a biological quality element since it increases the information towards a more realistic evaluation of the ecological potential of lentic freshwater ecosystems (e.g. Caroni \& Irvine, 2010; Jeppesen et al., 2011; Jensen et al., 2013).

The aim of this study was to assess the water quality in four reservoirs of the Cávado hydrographic basin (north of Portugal), according to the WFD approach. To further expand our knowledge of the contribution of zooplankton as a biological element to assess water quality of

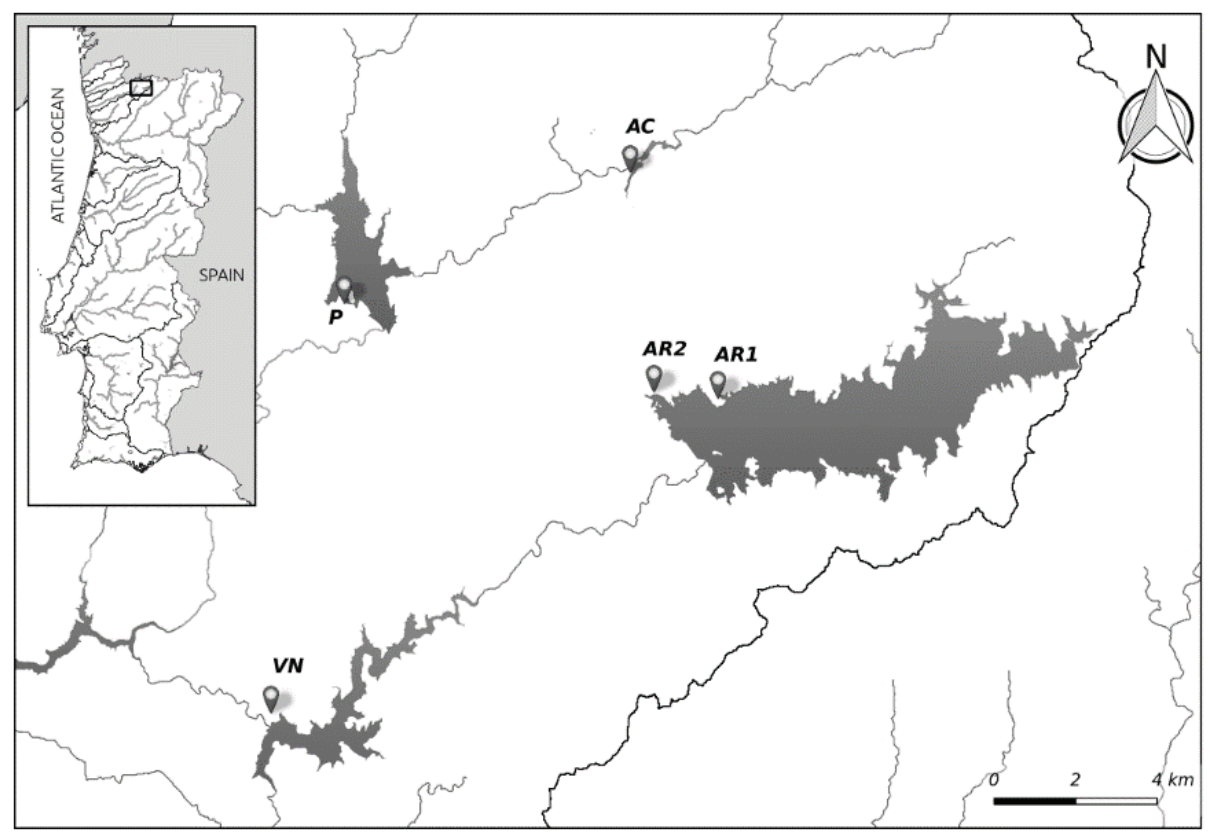

Figure 1. Location of each study site: VN - Venda Nova reservoir; AR1 and AR2 - two sampling sites at Alto Rabagão reservoir; AC - Alto Cávado reservoir; and P - Paradela reservoir. Ubicación de cada sitio de estudio: VN - Embalse de Venda Nova; AR1 y AR2: dos sitios de muestreo en el embalse Alto Rabagão; AC - Embalse Alto Cávado; y P - Embalse de Paradela. 
lentic aquatic ecosystems, a study of the dynamic of the zooplankton community was conducted. Indeed, we intend to compare the information provided by the two approaches, WFD metrics $v s$. dynamics of zooplankton community, to assess the ecological status of the lentic ecosystem (reservoirs).

\section{MATERIALS AND METHODS}

\section{Study Area}

The reservoirs chosen for conducting this study were located in the northern area of Portugal, in the Hydrographic Region of Rivers Cávado, Ave and Leça (RH2). This region is typically a mountainous area, characterized by its steep slopes and deep valleys, and a granitic bedrock is predominant in this area. This eastern limit of Cávado hydrographic basin shows a relatively high rainfall average (approximately $2200 \mathrm{~mm} /$ year) and an annual average temperature of $9.9^{\circ} \mathrm{C}$.

Four reservoirs were chosen: Venda Nova, Alto Rabagão, Alto Cávado, and Paradela, belonging to Cávado hydrographic basin (Fig. 1). All reservoirs were built for power energy exploitation and maintained by Energias de Portugal - EDP - for production of hydroelectric power. In Alto Cávado (AC), one sampling site was selected close to the dam wall $\left(41^{\circ} 48^{\prime}\right.$ $\left.06.122^{\prime \prime} \mathrm{N} ; 07^{\circ} 52^{\prime} 32.956^{\prime \prime} \mathrm{W}\right)$. This reservoir is the smallest reservoir of the study, with a water capacity of 3300 dam $^{3}$ and a 26 m dam wall. In Venda Nova reservoir (VN), one sampling site was chosen close to the dam wall $\left(41^{\circ} 40^{\prime}\right.$ $56.021 " \mathrm{~N} ; 07^{\circ} 58^{\prime} 56.056^{\prime \prime} \mathrm{W}$ ). This reservoir has a water capacity of $94500 \mathrm{dam}^{3}$ and the dam is 97 $\mathrm{m}$ high. In Paradela reservoir $(\mathrm{P})$, one sampling site was chosen $\left(41^{\circ} 46^{\prime} 22.521^{\prime \prime} \mathrm{N} ; 07^{\circ} 57^{\prime}\right.$ $37.203 " \mathrm{~W})$. This reservoir has a water capacity of $164390 \mathrm{dam}^{3}$ and a dam with $112 \mathrm{~m}$ of height. Two sampling sites were chosen in Alto Rabagão, AR1 (close to a trout farming: $41^{\circ} 45^{\prime} 10.808^{\prime \prime} \mathrm{N}$; $07^{\circ} 52^{\prime} 08.771 " \mathrm{~W}$ ), and AR2 (near the water input channel from Alto Cávado reservoir: $41^{\circ}$ $45^{\prime} 06.372^{\prime \prime} \mathrm{N} ; 07^{\circ} 51^{\prime} 0.547^{\prime \prime} \mathrm{W}$ ). This reservoir has a water capacity of $568690 \mathrm{dam}^{3}$, with a dam $94 \mathrm{~m}$ high, and it is the biggest reservoir of the study. All reservoirs are located in a rural area, with a very low population density, partially included in the protected area of National Park of Peneda-Gerês. The water from Venda Nova and Alto Rabagão is mainly used for agriculture and for domestic and urban supply. Alto Rabagão is also used for trout farming and for recreation. Alto Cávado is the only one among the four selected reservoirs that has a concession for sport fishing, legalized by the National Forestry Authority. Water from Paradela is only used for agricultural purposes (INAG, 2012).

\section{Sampling Procedure}

Seasonal sampling campaigns were carried out in 2014. In each sampling site, several parameters were measured in situ with a multiparametric probe, WTW Multi 350i: temperature, dissolved $\mathrm{O}_{2}, \mathrm{pH}$, conductivity and total dissolved solids. Additionally, surface water samples were collected in plastic bottles for further analysis of physical and chemical parameters in the laboratory: chlorophyll $a$; total suspended solids; nitrates, nitrites, ammonium, total phosphorus; biochemical oxygen demand after 5 days (BOD5) and turbidity. A simple discrete water sample collected sub-superficially was used to assess phytoplankton communities (INAG, 2009b). The water collected was brought to the laboratory in thermal bags and in the dark.

Macrozooplankton samples were collected using a hand net (mesh size $150 \mu \mathrm{m}$ ), performing five horizontal sub-surface trawls. Zooplankton samples were preserved in alcohol at $96 \%$ for later identification and counting in the laboratory.

\section{Physical and Chemical Analyses}

Nitrates were measured using a Hanna Intruments model C200 spectrophotometer, with a procedure based on an adaptation of the cadmium reduction method (method HI-93728-01, APHA, 1989), and total phosphorus concentration was determined using the ammonium molybdate-stannous chloride method described in APHA (1989). TSS, BOD5, nitrites, ammonia, and phosphate concentrations were determined according to standard protocols (APHA, 1989); turbidity was determined according to Brower et al. (1998). The 
Table 1. Functional groups of zooplankton community classification according to several authors: Gliwicz, 1977; Rieper, 1978; Geller \& Müller, 1981; DeMott \& Kerfoot, 1982; Porter et al., 1983; Carman \& Thistle, 1985; DeMott, 1985; Hessen, 1985; Bern, 1990; Adrian \& Frost, 1993; Bern, 1994; Seifried \& Dürbaum, 2000; Boxshall \& Halsey, 2004 Haberman \& Haldna, 2014. Grupos funcionales de clasificación de la comunidad de zooplancton según varios autores: Gliwicz, 1977; Rieper, 1978; Geller \& Müller, 1981; DeMott \& Kerfoot, 1982; Porter et al., 1983; Carman \& Thistle, 1985; DeMott, 1985; Hessen, 1985; Bern, 1990; Adrian \& Frost, 1993; Bern, 1994; Seifried \& Dürbaum, 2000; Boxshall \& Halsey, 2004 Haberman \& Haldna, 2014.

\begin{tabular}{|c|c|}
\hline FUNCTIONAL GROUP & TAXA RECORDED IN THIS STUDY \\
\hline High-efficiency bacteria feeders (HE) & $\begin{array}{l}\text { Ceriodaphnia sp.; Chydorus sp.; Alonella sp.; } \\
\text { Acroperus sp.; Leydigia sp.; Eurycerus sp.; } \\
\text { Macrothricidae }\end{array}$ \\
\hline Low-efficiency bacteria feeders (LE) & Daphnia longispina; Bosmina sp.; Simocephalus sp. \\
\hline Macrofiltrators (M) & Holopedium sp.; Sid asp.; Calanoida \\
\hline Omnivores (Om) & Cyclopoida; Harpaticoida \\
\hline
\end{tabular}

quantification of photosynthetic parameters (chlorophyll a) was conducted according to Lorenzen (1967) method.

\section{Plankton community analysis}

For phytoplankton analysis, $500 \mathrm{~mL}$ of the water collected in each sampling site were left to sediment for one week, with Lugol solution (final dilution of 1:100). After this period the sedimented phytoplankton community was collected, by decantation, and analyzed. Phytoplankton samples were identified using specific identification keys (e.g. Bellinger \& Sigee, 2015). From each phytoplankton sample, six subsamples were counted using a Neubauer chamber, until 400 individuals were counted. The guidelines from WFD were followed to calculate the Ecological Quality Ratios [EQR = (1 / value determined $)$ / (1 / reference value)] according to four phytoplankton composition metrics: Chlorophyll $a$ concentration; \% Biovolume of cyanobacteria; total phytoplankton biovolume; and the IGA (Index group algae), also known as the Catalan Index (Catalan et al., 2003).

Zooplankton samples were identified using a standard binocular magnifying glass. Macrozooplankton organisms from the groups Cladocera and Copepoda were identified and counted using proper identification keys: Harding \& Smith (1974), Amoros (1984) and Alonso (1996).

\section{Data Analysis}

Physical and chemical parameters, and phytoplankton indicators were analysed comparing the values determined to the reference values defined by WFD for Heavily Modified Waterbodies (reservoirs) of the north of Portugal (INAG, 2009). Carlson's Trophic State Index (TSI) was calculated with the chlorophyll $a$ values (Carlson, 1977).

The structure and composition of zooplankton communities were analysed through descriptive statistical methods (Species richness, Shannon Diversity Index and Pielou Evenness Index) in order to determine the relative abundance and variation of the zooplankton groups for each reservoir along the sampling period. Different zooplankton metrics/indices were used, such as the ratio of large cladoceran abundance to total cladoceran abundance - which was used to understand the intensity of fish predation in the reservoirs (Moss et al., 2003; Haberman \& Haldna, 2014). Moreover, the zooplankton taxa were divided into functional ecological groups according to Geller \& Müller (1981) (Table 1) and groups fluctuations were compared with their established seasonal patterns established for different trophic states. Additional information portraying other taxa not present in Geller \& Müller (1981) were found in the literature (DeMott \& Kerfoot, 1982; Porter, 1983). 
Cyclopoida were added to the present study as omnivores (Adrian \& Frost, 1993), as well as Harpacticoida (Rieper, 1978; Carman \& Thistle, 1985; Seifried \& Dürbaum, 2000; Boxshall $\&$ Halsey, 2004). Chydoridae and Macrothricidae were considered high efficiency bacteria feeders (Gliwicz, 1977; Geller \& Müller's, 1981; DeMott, 1985; Hessen, 1985; Bern, 1990; Bern, 1994).

Canonical correspondence analysis (CCA) was used to examine the main sources of variation in the zooplankton communities. Two explanatory matrices were considered when building the CCA models for the relative abun- dance data of the zooplankton (5 sites $\times 4$ sampling seasons): 1) physical and chemical data and 2) phytoplankton metrics. A CCA-derived variation partitioning technique (Borcard et al., 1992; Økland \& Eilersten, 1994) was used to quantify the variation explained by each matrix. This was performed by partialling out (as covariables) each of the subsets of explanatory variables at a time and comparing the percentage of variance explained by the partial CCAs with the one obtained with the global CCA model (physical and chemical data + phytoplankton metrics). All these multivariate analyses were performed using CANOCO for Windows version 4.5.

Table 2. Physical and chemical parameters measured in water samples for each site along the sampling period, with the limit values for good ecological potential (GEP) according to WFD for highly modified water bodies (reservoirs) and ecological water classification (INAG, 2009). BDL - below detected limit $(0.10 \mathrm{mg} / \mathrm{L})$, bold values stand for values out the stipulated range. Parámetros físicos y químicos de soporte general medidos en muestras de agua para cada sitio a lo largo del periodo de muestreo, con los valores límite a buen potencial ecológico (GEP) según WFD para cuerpos de agua altamente modificados (reservorios) y clasificación ecológica del agua (INAG, 2009). BDL - por debajo del límite detectado $(0.10 \mathrm{mg} / \mathrm{L})$, los valores en negrita representan valores fuera del rango estipulado.

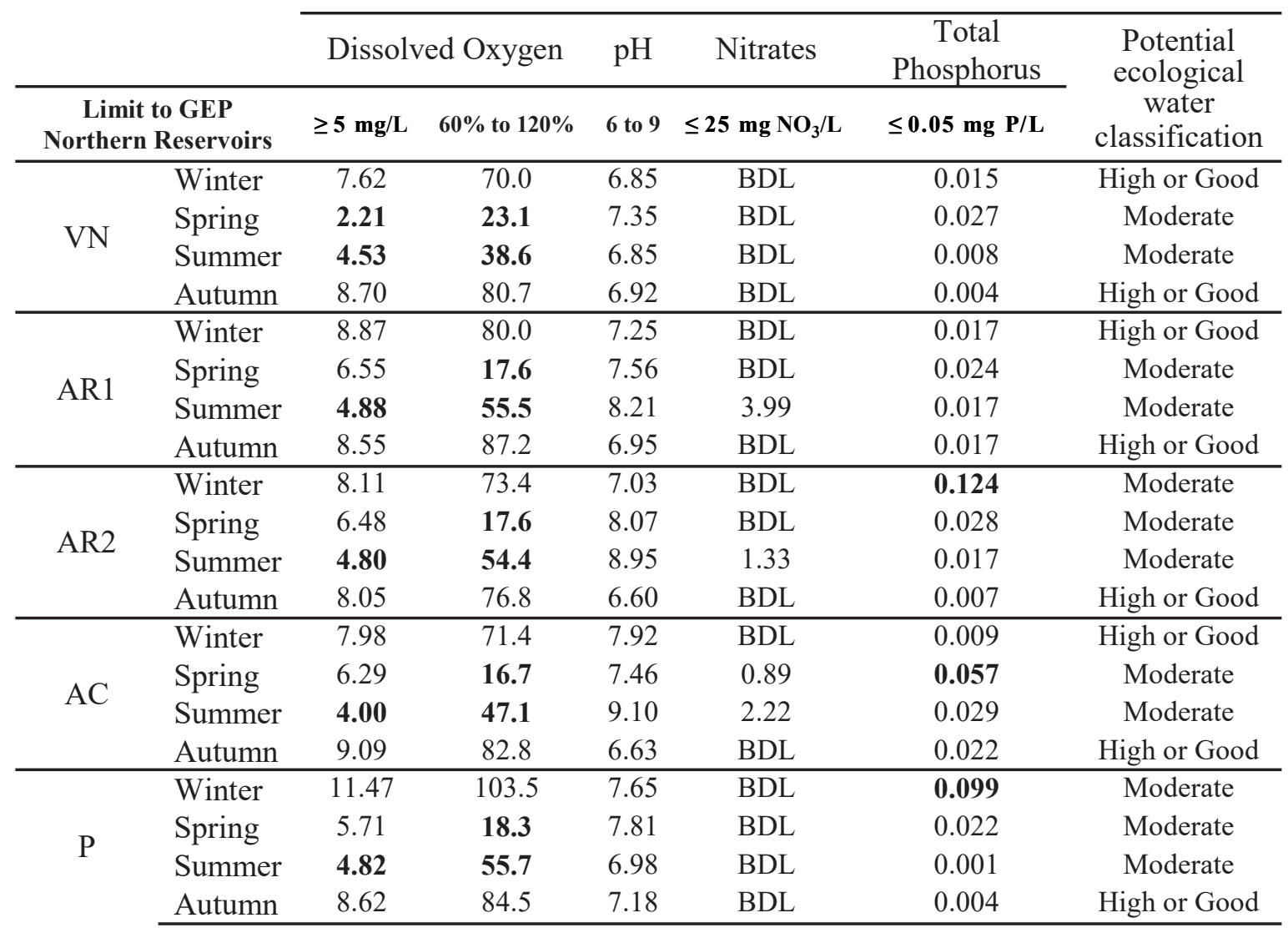




\section{RESULTS}

\section{Physical and Chemical Parameters}

Table 2 presents the values for physical and chemical parameters obtained in the four sampling campaigns in Winter, Spring, Summer, and Autumn. The threshold values established for the "Good Ecological Potential" (GEP) for Northern Reservoirs of Portugal (INAG, 2009) are also displayed on the table for comparison. For the dissolved oxygen, all the sampling sites had values under $5 \mathrm{mg} / \mathrm{L}$ or less than $60 \%$ saturation (threshold values for GEP of northern reservoirs; INAG, 2009) during Spring and Summer. These low dissolved oxygen values were registered when water reached higher temperatures (Table 3). $\mathrm{pH}$ ranged from 6.60 to 9.10 , meeting the criterion of $\mathrm{pH}$ values in the 6 to 9 range, required for the GEP. Moreover, $\mathrm{pH}$ values were consistent through the entire year in all the studied reservoirs. Although some variations occurred in the concentrations of nitrates during the sampling period, all the sampling sites had the required annual average concentrations under the maximum limit of 25 $\mathrm{mg} / \mathrm{L}$ for GEP of northern reservoirs. Most of the sampling periods displayed nitrate concentrations under $0.10 \mathrm{mg} / \mathrm{L}$; the highest value obtained was $3.99 \mathrm{mg} / \mathrm{L}$, registered during Summer in Alto Rabagão (AR1). Similarly, the concentrations of total phosphorus were very low for all sampling sites through most of the seasons, although higher

Table 3. Other relevant physical and chemical parameters measured in water samples for each site along the sampling period. Cond - Conductivity, TSS - Total Suspended Solids, BOD5 - biochemical oxygen demand after 5 days, Turb - turbidity, Temp - Temperature, $\mathrm{NO}_{2}{ }^{-}$- Nitrites, $\mathrm{NH}_{4}{ }^{+}$- Ammonium, and TSI - Trophic State Index (O - Oligotrophic, M - Mesotrophic, E - Eutrophic). Otros parámetros físicos y químicos relevantes medidos en muestras de agua para cada sitio a lo largo del período de muestreo. Cond Conductividad, TSS - Sólidos Suspendidos Totales, DBO5 - demanda bioquímica de oxígeno después de 5 días, turbiedad - turbidez, temperatura - temperatura, $\mathrm{NO}_{2}^{-}$- nitritos, $\mathrm{NH}_{4}^{+}$- amonio, e TSI - índice de estado trófico (O - oligotrófico, $M$ - Mesotrófico, E Eutrófico).

\begin{tabular}{|c|c|c|c|c|c|c|c|c|c|}
\hline & & $\begin{array}{l}\text { Cond } \\
\mu \mathrm{S} / \mathrm{cm}\end{array}$ & $\begin{array}{c}\text { TSS } \\
\text { mg/L }\end{array}$ & $\begin{array}{c}\text { BOD5 } \\
\mathrm{mg} / \mathrm{L}\end{array}$ & $\begin{array}{c}\text { Turb } \\
\mathbf{m}^{-1}\end{array}$ & $\begin{array}{c}\text { Temp } \\
{ }^{\circ} \mathrm{C}\end{array}$ & $\begin{array}{l}\mathrm{NO}_{2}^{-} \\
\mathrm{mg} / \mathrm{L}\end{array}$ & $\begin{array}{l}\mathrm{NH}_{4}{ }^{+} \\
\mathrm{mg} / \mathrm{L}\end{array}$ & $\begin{array}{c}\text { TSI } \\
(\operatorname{chl} a)\end{array}$ \\
\hline \multirow{4}{*}{ VN } & Winter & 18.9 & 2.88 & 1.37 & 0.004 & 11.0 & 0.00 & 0.37 & $36(\mathrm{O})$ \\
\hline & Spring & 20.9 & 9.72 & 1.78 & 0.002 & 17.2 & 0.00 & 0.01 & $41(\mathrm{M})$ \\
\hline & Summer & 23.0 & 24.2 & 1.79 & 0.006 & 23.0 & 0.05 & 0.01 & $42(\mathrm{M})$ \\
\hline & Autumn & 20.2 & 6.65 & 1.44 & 0.003 & 11.5 & 0.00 & 0.54 & $65(\mathrm{E})$ \\
\hline \multirow{4}{*}{ AR1 } & Winter & 21.0 & 8.15 & 0.99 & 0.005 & 10.8 & 0.36 & 0.01 & $47(\mathrm{M})$ \\
\hline & Spring & 21.4 & 6.92 & 1.92 & 0.001 & 16.7 & 0.00 & 0.01 & $44(\mathrm{M})$ \\
\hline & Summer & 21.7 & 11.1 & 0.55 & 0.003 & 20.8 & 0.00 & 0.13 & $45(\mathrm{M})$ \\
\hline & Autumn & 21.8 & 8.16 & 2.32 & 0.007 & 12.1 & 0.02 & 0.07 & $50(\mathrm{M})$ \\
\hline \multirow{4}{*}{ AR2 } & Winter & 21.7 & 5.52 & 1.46 & 0.006 & 10.7 & 0.00 & 0.01 & $42(\mathrm{M})$ \\
\hline & Spring & 21.5 & 9.02 & 2.08 & 0.007 & 16.9 & 0.00 & 0.01 & $46(\mathrm{M})$ \\
\hline & Summer & 21.6 & 13.0 & 0.57 & 0.006 & 20.6 & 0.00 & 0.03 & $46(\mathrm{M})$ \\
\hline & Autumn & 21.9 & 8.21 & 1.48 & 0.003 & 12.2 & 0.03 & 0.11 & $37(\mathrm{O})$ \\
\hline \multirow{4}{*}{$\mathrm{AC}$} & Winter & 22.6 & 8.15 & 0.28 & 0.008 & 8.80 & 0.00 & 0.01 & $35(\mathrm{O})$ \\
\hline & Spring & 24.9 & 6.92 & 1.83 & 0.013 & 17.5 & 0.01 & 0.26 & $53(\mathrm{E})$ \\
\hline & Summer & 39.1 & 11.1 & 0.93 & 0.009 & 22.9 & 0.00 & 0.22 & $46(\mathrm{M})$ \\
\hline & Autumn & 21.8 & 7.13 & 0.34 & 0.008 & 10.3 & 0.25 & 0.81 & $31(\mathrm{O})$ \\
\hline \multirow{4}{*}{$\mathrm{P}$} & Winter & 13.6 & 5.72 & 0.66 & 0.002 & 10.0 & 0.00 & 0.19 & $38(\mathrm{O})$ \\
\hline & Spring & 14.9 & 10.7 & 2.07 & 0.018 & 19.3 & 0.00 & 0.01 & $38(\mathrm{O})$ \\
\hline & Summer & 16.0 & 15.5 & 0.28 & 0.002 & 21.8 & 0.11 & 0.08 & $36(\mathrm{O})$ \\
\hline & Autumn & 11.9 & 6.21 & 0.65 & 0.001 & 13.0 & 0.54 & 0.09 & $34(\mathrm{O})$ \\
\hline
\end{tabular}


values were recorded during Winter (AR and $\mathrm{P}$ ) and Spring (AC). The remaining values were all under the maximum limit for the good ecological potential in all sampled reservoirs. According to these physical and chemical parameters, a high or good ecological potential was always achieved in autumn for all sites, while in spring and summer the classification was only moderate.

Additionally, another set of environmental parameters was assessed, due to their relevance for the functioning and stability of the ecosystems (Table 3). Conductivity values were low, ranging from $11.9 \mu \mathrm{S} / \mathrm{cm}$ in Paradela in Autumn to 39.1 $\mu \mathrm{S} / \mathrm{cm}$ in Alto Cávado in Summer. For TSS, both the minimum and maximum values $(2.88 \mathrm{mg} / \mathrm{L}$ and $24.2 \mathrm{mg} / \mathrm{L}$, respectively) were observed in Venda Nova reservoir in Winter and Summer, respectively. During Winter, Alto Cávado presented the lowest value for BOD5 $(0.34 \mathrm{mg} / \mathrm{L})$, while the maximum value $(2.32 \mathrm{mg} / \mathrm{L})$ was obtained in AR1 in Autumn. All sampling sites had very clear water, and presented low turbidity values, ranging from $0.001 \mathrm{~m}^{-1}$ to $0.013 \mathrm{~m}^{-1}$. Temperature varied according to seasonality along the year, with the lowest values recorded in Winter and the highest values observed in Summer. Nutrient concentrations were low. More specifically, for almost the samples, the concentration of nitrates was below the detection limit, and the maximum value obtained was $0.36 \mathrm{mg} / \mathrm{L}$ in AR1 in Winter. Ammo-

Table 4. Normalized Ecological Quality Ratios (EQR) for the four phytoplankton composition metrics: Chlorophyll $a$ concentration; $\%$ Biovolume of cyanobacteria; total phytoplankton biovolume; and the IGA (Index group algae), also known as the Catalan Index (Catalan et al., 2003) for each sampling site along the studied period and ecological classification according to these WFD metrics. Relaciones de calidad ecológica normalizada (EQR) a las cuatro métricas de composición del fitoplancton: Concentración de clorofila a; \% Biovolumen de cianobacterias; biovolumen total de fitoplancton; y el IGA (grupo de índice de algas), también conocido como el Índice Catalán (Catalán et al., 2003) para cada sitio de muestreo a lo largo del período estudiado y la clasificación ecológica según esta métrica de la DMA.

\begin{tabular}{|c|c|c|c|c|c|c|c|}
\hline & \multirow{3}{*}{$\begin{array}{c}{[\mathrm{Chl} a]} \\
2.00 \\
(0.21) \\
\end{array}$} & \multirow{3}{*}{$\begin{array}{c}\begin{array}{c}\text { Total } \\
\text { Biovolume }\end{array} \\
0.36 \\
(0.19) \\
\end{array}$} & \multirow{3}{*}{$\begin{array}{c}\text { \% biovolume } \\
\text { Cyanobacteria } \\
0.00 \\
(0.91) \\
\end{array}$} & \multirow{3}{*}{$\begin{array}{c}\text { IGA } \\
0.10 \\
(0.97) \\
\end{array}$} & \multirow{3}{*}{$\begin{array}{c}\text { EQR } \\
\text { phytoplankton } \\
>0.6\end{array}$} & \multirow{3}{*}{$\begin{array}{c}\text { Ecological } \\
\text { Potential } \\
\text { status (WFD) }\end{array}$} \\
\hline & & & & & & & \\
\hline $\begin{array}{c}\text { Thresl } \\
\text { northe }\end{array}$ & $\begin{array}{l}d \text { values to GEP } \\
\text { reservoirs (EQR) }\end{array}$ & & & & & & \\
\hline \multirow{4}{*}{$\mathrm{VN}$} & Winter & 1.06 & 0.64 & 0.99 & 0.60 & 0.8 & Good or High \\
\hline & Spring & 0.84 & 0.80 & 0.67 & 1.88 & 1.1 & Good or High \\
\hline & Summer & 0.81 & 0.78 & 0.71 & 1.94 & 1.1 & Good or High \\
\hline & Autumn & 0.16 & 0.95 & 0.81 & 1.96 & 1.0 & Good or High \\
\hline \multirow{4}{*}{ AR1 } & Winter & 0.81 & 0.67 & 0.97 & 0.41 & 0.6 & Good or High \\
\hline & Spring & 0.75 & 0.72 & 0.94 & 0.59 & 0.8 & Good or High \\
\hline & Summer & 0.60 & 0.64 & 0.97 & 1.94 & 1.0 & Good or High \\
\hline & Autumn & 0.63 & 1.00 & 0.74 & 1.85 & 1.1 & Good or High \\
\hline \multirow{4}{*}{ AR2 } & Winter & 0.81 & 0.68 & 0.97 & 1.76 & 1.1 & Good or High \\
\hline & Spring & 0.70 & 0.93 & 0.82 & 1.81 & 1.1 & Good or High \\
\hline & Summer & 0.31 & 0.61 & 0.97 & 1.97 & 1.0 & Good or High \\
\hline & Autumn & 1.01 & 1.48 & 0.85 & 1.65 & 1.3 & Good or High \\
\hline \multirow{4}{*}{$\mathrm{AC}$} & Winter & 1.12 & 0.66 & 0.58 & 0.58 & 0.7 & Good or High \\
\hline & Spring & 0.60 & 0.83 & 0.81 & 1.99 & 1.1 & Good or High \\
\hline & Summer & 0.37 & 0.63 & 0.96 & 1.96 & 1.0 & Good or High \\
\hline & Autumn & 1.44 & 0.71 & 0.96 & 1.86 & 1.2 & Good or High \\
\hline \multirow{4}{*}{$\mathrm{P}$} & Winter & 0.97 & 0.69 & 0.91 & 1.99 & 1.1 & Good or High \\
\hline & Spring & 0.97 & 0.85 & 0.93 & 2.00 & 1.2 & Good or High \\
\hline & Summer & 1.92 & 0.50 & 0.96 & 1.98 & 1.3 & Good or High \\
\hline & Autumn & 1.20 & 1.60 & 0.71 & 1.90 & 1.4 & Good or High \\
\hline
\end{tabular}


Table 5. Species Richness, Shannon Diversity Index and Pielou Evenness results of zooplankton communities. Riqueza de especies, índice de diversidad de Shannon y resultados de uniformidad de Pielou de las comunidades de zooplancton.

\begin{tabular}{|c|c|c|c|c|}
\hline & & $\begin{array}{c}\text { Species } \\
\text { Richness } \\
\end{array}$ & $\begin{array}{c}\text { Shannon } \\
\text { Diversity Index }\end{array}$ & $\begin{array}{c}\text { Pielou } \\
\text { Evenness }\end{array}$ \\
\hline \multirow{4}{*}{$\mathrm{VN}$} & Winter & 8 & 0.803 & 0.386 \\
\hline & Spring & 7 & 1.521 & 0.782 \\
\hline & Summer & 8 & 1.114 & 0.536 \\
\hline & Autumn & 7 & 0.649 & 0.334 \\
\hline \multirow{4}{*}{ AR1 } & Winter & 12 & 1.900 & 0.745 \\
\hline & Spring & 8 & 0.873 & 0.420 \\
\hline & Summer & 13 & 1.821 & 0.710 \\
\hline & Autumn & 10 & 0.889 & 0.387 \\
\hline \multirow{4}{*}{ AR2 } & Winter & 11 & 1.360 & 0.567 \\
\hline & Spring & 10 & 0.991 & 0.431 \\
\hline & Summer & 10 & 0.841 & 0.365 \\
\hline & Autumn & 11 & 1.400 & 0.584 \\
\hline \multirow{4}{*}{$\mathrm{AC}$} & Winter & 8 & 1.771 & 0.852 \\
\hline & Spring & 10 & 1.264 & 0.549 \\
\hline & Summer & 7 & 1.521 & 0.781 \\
\hline & Autumn & 8 & 1.204 & 0.579 \\
\hline \multirow{4}{*}{$\mathrm{P}$} & Winter & 7 & 0.518 & 0.266 \\
\hline & Spring & 8 & 0.955 & 0.459 \\
\hline & Summer & 8 & 1.198 & 0.576 \\
\hline & Autumn & 5 & 1.252 & 0.779 \\
\hline
\end{tabular}

nium concentration was also very low for almost the samples $(0.01 \mathrm{mg} / \mathrm{L})$, and the highest concentration was $0.37 \mathrm{mg} / \mathrm{L}$ at $\mathrm{VN}$ in Winter. Phosphate was the only nutrient that showed more variation throughout the year and amongst sampling sites, with values between $0.02 \mathrm{mg} / \mathrm{L}$ (AR2 in Spring) and $7.41 \mathrm{mg} / \mathrm{L}$ (P in Autumn). TSI values, based on chlorophyll $a$ concentration, were calculated and most of them fitted within the oligotrophic and mesotrophic state values $(0$ to $<40$ and $>40$ to $<$ 50, respectively; Carlson, 1977). VN was the reservoir that displayed the highest variation in TSI values, in contrast to $P$, which was simultaneously the reservoir with lower TSI values and less variation throughout the sampling period.

\section{Phytoplankton communities}

The values for the EQR of phytoplankton are displayed in Table 4 (more details in table S1, available at http://www.limnetica.net/en/limnetica). According to the WFD guidelines, for Northern Reservoirs of Portugal, an average EQR value for phytoplankton higher or equal to 0.6 means that the water body is classified as having good or higher ecological potential. The results obtained in this study show a slight variation in the EQR values among the studied reservoirs, with all scored values above the threshold and, therefore, all classified as having good or higher ecological potential. Paradela, was the one scoring the highest EQR value for phytoplankton, 1.4 in Autumn, and a sampling site from AR1 scored the lowest value $(\mathrm{EQR}=0.6)$.

Regarding the partial EQR values for each phytoplankton composition metrics, the EQR values for $\mathrm{Chl} a$ concentration ranged from 0.16 (for VN in Autumn) to 1.92 (for P in Summer). The lowest value for Total Biovolume was 0.50, for $\mathrm{P}$ in Summer, and the highest was 1.60, for $\mathrm{P}$ 
in Autumn. The EQR for the \% biovolume of Cyanobacteria showed relatively low variation, with most values being above 0.90 , and ranging from 0.53 to 0.99 . The IGA values were comprehended between 0.41 (for AR1 in winter) and 2.00 (for P in Spring).

\section{Zooplankton communities}

Diversity indices (Species Richness, Shannon Diversity Index and Pielou Evenness) are presented in Table 5. The highest values for species richness were registered in both sampling sites from Alto Rabagão reservoir, with 13 taxa in AR1 in Summer. The lowest value for species richness was registered in P in Autumn, when only 5 taxa were registered. For the Shannon Diversity Index, the highest value was again registered in AR1 in Spring, and the lowest value was observed in $\mathrm{P}$ in Winter. Regarding Evenness, the maximum value was 0.852 in $\mathrm{AC}$ in Winter, and the lowest value was 0.266 in $\mathrm{P}$ in Winter.

The zooplankton taxa identified in the samples (Table S1) were divided into 4 functional groups (Table 1) and the dynamics of the zooplankton groups for each sampling site during the sampling period are displayed in Figure 2. In Venda Nova, the community switched from being mainly dominated by omnivorous taxa (in Winter), namely Cyclopoida, to a dominance of macrofiltrators during Summer; in Autumn, the zooplankton community was almost entirely composed by high-efficiency bacteria feeders, namely Ceriodaphnia sp.. These shifts in community composition were accompanied by a decrease in the presence of larger cladoceran taxa. The same tendency was observed in both sampling sites from Alto Rabagão (AR1 and AR2), where a consistent decrease in the presence of large-bodied cladocerans was registered throughout the year. In AR1, an increase of macrofiltrators was observed in Spring, due to a high density of Holopedium sp., and, afterwards, the populations of high-efficiency bacteria feeders increased and became dominant in Autumn, when the community was mostly dominated by Ceriodaphnia sp.. In AR2, a dominance of low-efficiency bacteria feeders was observed in Winter. Then, a shift to a community dominated
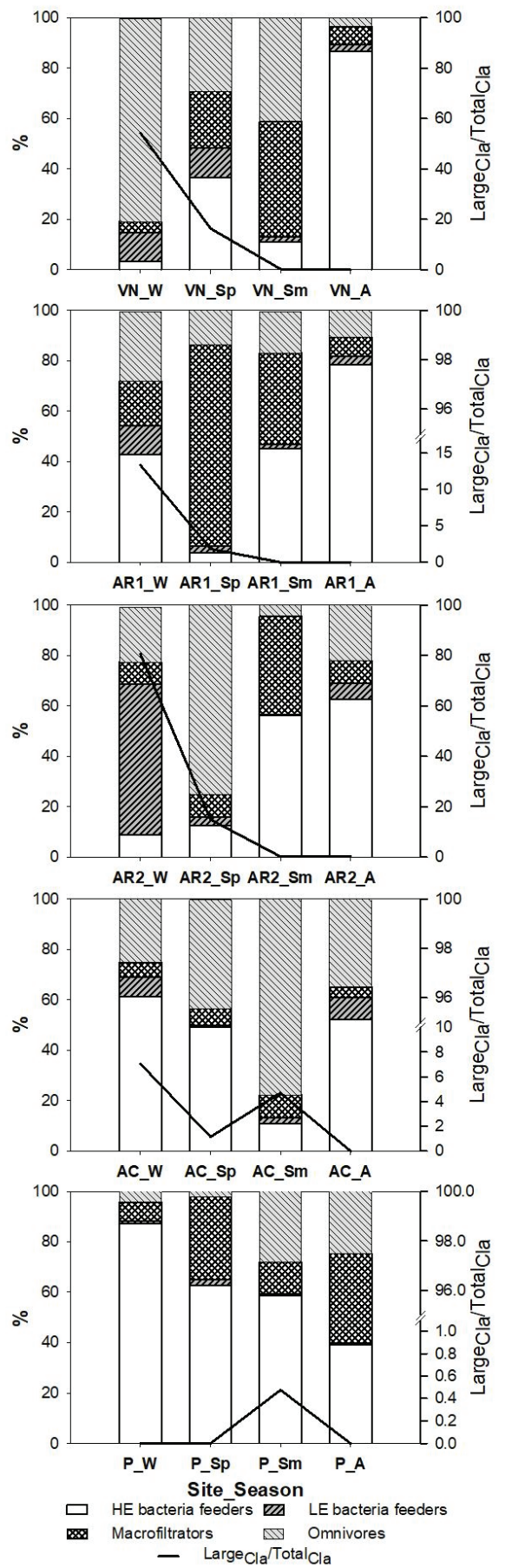

Figure 2. Dynamic of zooplankton community according to functional groups (see Table 4) in the 5 sampling sites (VN, $\mathrm{AR} 1, \mathrm{AR} 2, \mathrm{AC}$, and $\mathrm{P}$ ) for the 4 sampling periods (W-winter, Sp-Spring, Sm-Summer, and A-Autumn). Dinámica de la comunidad de zooplancton según los grupos funcionales (ver tabla 4) en los 5 sitios de muestreo (VN, AR1, AR2, AC y P) para los 4 periodos de muestreo ( $W$-invierno, Sp-primavera, Sm-verano, y A-otoño). 


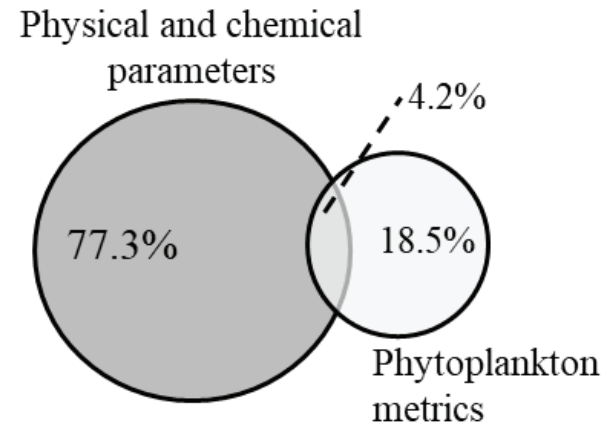

Figure 3. Venn diagram showing the partition of the total variation of the zooplankton community data across two sets of explanatory variables (physical and chemical data + phytoplankton metrics). Sum of all canonical eigenvalues for global model $=2.04$. Diagrama de Venn que muestra la partición de la variación total de los datos de la comunidad zooplanctónica en dos conjuntos de variables explicativas (datos fisicos y químicos + métricas de fitoplancton). Suma de todos los valores propios canónicos para el modelo global $=2.04$.

by omnivorous taxa and an increase in the populations of high-efficiency bacteria feeders was recorded in Spring. Alto Cávado reservoir showed an interchanging dominance of high-efficiency bacteria feeders, due to the considerable presence of Leydigia sp., Alonella sp. and Chydorus sp., and low-efficiency bacteria feeders taxa along the year. Unlike Venda Nova and Alto Rabagão, after a small decrease in the presence of larger cladocerans in Spring, Alto Cávado showed a second peak of these large-bodied zooplankton taxa in Summer. Paradela seems to have the most stable communities, with the dominance of high-efficiency bacteria feeders, mostly Ceriodaphnia sp., during most of the year; macrofiltrators, represented by Holopedium sp., were the second most abundant group observed. Contrary to the other reservoirs, a greater presence of large cladocerans was not registered in $\mathrm{P}$ during winter, although a small increase of this group occurred in Summer.

Using partial CCAs, we show that the contribution of physical and chemical data is much higher (sum of all canonical eigenvalues $=1.57$ ) than that of phytoplankton metrics (sum of all canonical eigenvalues $=0.376$ ) to explain variation in the zooplankton community - see varia- tion partition in figure 3 . A negligible portion of variation $(4.2 \%)$ resulted from the intersection of both sets of explanatory variables (physical and chemical parameters and phytoplankton metrics).

\section{DISCUSSION}

Using the guidelines and thresholds for physical and chemical parameters, established in the WFD for this type of Heavily Modified Waterbodies (INAG, 2009), the reservoirs assessed in this study showed stability and homogeneity in water quality across the sampling period and amongst each other, displaying similar values for all criteria across the year. The parameter that showed the highest variation was dissolved $\mathrm{O}_{2}$ (both in $\mathrm{mg} / \mathrm{L}$ and $\%$ saturation), which was inversely proportional to water temperature. This variation in oxygen concentration is natural and was expected, as it is known that the ability of water to incorporate $\mathrm{O}_{2}$ decreases as temperature increases (Czerniawski \& Domagała, 2010; Celekli \& Öztürk, 2014), and therefore lower concentrations of $\mathrm{O}_{2}$ are usually registered during warmer months; indeed, our results showed a very low oxygen concentration in this period. The variation of this parameter was responsible for the classification of "Moderate Ecological Potential" in spring and summer (Table 2). The variation in classification is due to a parameter that varies according to its natural pattern, so it may be an indication that the ecosystems were little disturbed by external factors. All the reservoirs are located in rural areas, isolated and subjected to very low anthropogenic disturbance, being surrounded by forest and natural areas or small agricultural holdings (Cabecinha et al., 2009a; Cabecinha et al., 2009b; Santos et al., 2015). Indeed, several studies have shown a relationship between land use in the watershed and water quality (Smith et al., 1999; Pan et al., 2004; Lee et al., 2009). Waterbodies surrounded by agricultural fields and croplands are subjected to larger inflows of nutrients, resultant from the application of fertilizers and manures on the soils (Turner \& Rabalais, 2003; Navarro et al., 2009). Therefore, the systems of the present study were expected to have good water quality and show low disturbance, besides those caused by the dam 
and the leaching from the surrounding areas. These reservoirs had annual classifications of GEP in most of the past ten years according to the data available in SNIRH (Sistema Nacional de Informação de Recursos Hídricos) database. Even though there is low agricultural pressure in the surrounding area, some input of nutrients from leaching was expected (e.g. nitrates and phosphorus), which was observed in the nutrient concentrations in all reservoirs (Table 2). Thus, the occasional classification of Moderate Ecological Potential was due to unusual leaching of nutrients and microbial content described for these reservoirs (see https://snirh.apambiente.pt). Venda Nova was the only one that obtained a classification of Bad during the last 10 years, due to an unusually high concentration of phosphates (see https://snirh.apambiente.pt). However, and according to Cabecinha et al. (2009a), these reservoirs can be considered as a reference for Good Ecological Potential, based on environmental data assessed by the Laboratory of Environmental and Applied Chemistry (LABELEC). The data obtained in this study (sample period between 1996 and 2004) recorded values of $\mathrm{pH}$ (range 7.70 to 8.23 ), dissolved oxygen (range 7.98 to 10.8 ) and nitrates (range 0.7 to 7.93 ) that are comparable to the ones obtained during the present sampling campaign (Cabecinha et al., 2009a). This shows that the quality of the water of these reservoirs has been kept good and stable in the past years.

Although environmental parameters appear to have had reasonably homogenous variations, the information provided by the phytoplankton community did not show any alterations. Several authors have argued the importance of using more biological elements to evaluate water quality and the ecological status of aquatic systems (Cabecinha et al., 2009a; Martinez-Haro et al., 2015). Phytoplankton has been documented as being highly sensitive to alterations on the nutrient concentrations in the water (Schindler, 1977) and, it is so far the only biological element proposed and established by WFD for lentic ecosystems. However, based on our results of the phytoplankton analysis, under the WFD approach, no variations were observed in the reservoir water classification (Table 4$)$. On the other hand, considering the distinct variations of the TSI ( Chl $a$ ) observed on the reservoirs, it is possible to assume that they suffered different pressures along the year. Venda Nova was the reservoir that presented higher variations in the structure of phytoplankton communities, due to great decrease of the water level in May, namely caused by works in the dam, and the rise to normal levels in October. Indeed, the analysis of TSI (Chl $a$ ) for this reservoir reflects the impact of this variation in the ecosystem. These fluctuations in the water level caused not only the resuspension of sediments and deposited organic matter, but also the flooding of soils in the margins. The resuspension of sediments can be associated with an increase in the concentration of phosphorus, as demonstrated by Kristensen (1992). Flooding of soils can cause an increase in the concentration of nutrients in the water body, such as nitrates and phosphorus, responsible for the eutrophication processes (McCartney et al., 1999; Navarro et al., 2009). This may explain the increase on the TSI (Chl $a$ ) values observed in Autumn in Venda Nova reservoir, when the rise of the water level may increase the nutrient concentrations from the exposed soils, leading the ecosystem to the state of eutrophic. Alto Cávado also showed high variation in TSI (Chl $a)$ across the year (Table 3 ), however this reservoir is the smallest reservoir studied $\left(\approx 3300 \mathrm{dam}^{3}\right)$. According to Padisák et al. (2003), smaller reservoirs are more vulnerable to changes caused by climatic variations and human activities, therefore subjected to more variations in the phytoplankton community.

When compared with the TSI results, many of the species shifts in zooplankton communities coincide with changes in the trophic status. A slight increase of TSI values was verified in Autumn in Venda Nova, and Spring in Alto Cávado, both classified as eutrophic reservoirs (Table 3). In this period, we recorded an increase of small-bodied cladocerans, which are considered efficient bacterial feeders (Jensen et al., 2013), as well as an increase in species more tolerant to eutrophication, such as Ceriodaphnia sp. (Azevêdo et al., 2015), demonstrating that macrozooplankton community may reflect the changes in water quality. Amoros (1984) also 
described most Ceriodaphnia species as being very tolerant to high trophic status, thus explaining the high presence of these organisms in months when high trophic state index values were registered. In Autumn in Venda Nova reservoir a considerable increase in the trophic state was verified and it was coincident with a major switch in the dominance in the macrozooplanktonic community. Holopedium sp. populations, which are highly associated to environments with low trophic states (Jensen et al., 2013), were almost suppressed, and Ceriodaphnia sp. became dominant. The same increase of small-bodied cladocerans (high efficient bacterial feeders) was observed in the same period in AR1. Copepods are usually more representative in Spring months (Nogueira, 2001). This was also observed in our results for most of the sampling sites, since copepods where more abundant until Summer. Then, coincidently with an increase of TSI values for most of the sampling sites, the communities were manly composed by cladocerans, while Copepoda were less represented. The increase of primary production may cause the growth of cladocerans, which are the most efficient filtering species of the zooplankton (Hessen et al., 2006).

Zooplankton community species richness is also related to the size of the reservoir. Usually, species richness increases with the increase of ecosystem volume (O'Brien et al., 2004). In our results, the reservoirs that showed higher species richness were Alto Rabagão and Alto Cávado. Alto Rabagão was the largest studied reservoir and had the highest species richness overall (Table 5). On the other hand, Alto Cávado is the smallest and shallower of the sampling sites but it also showed very high species richness. When analysing the species found in Alto Cávado, many were littoral species, such as Leydigia sp. and Alonella sp. (Alonso, 1996), and could only be found in samples from this reservoir. Indeed, this reservoir presented a low depth and reduced slope in the margins associated to an high density of submerged vegetation and macrophytes, which allow refuge and nursery areas for pelagic and littoral species (Hessen et al., 2006).

Paradela reservoir had the higher stability of the zooplanktonic community. The high density of Holopedium sp., a species very intolerant to eutrophication phenomena (Jensen et al., 2013), and the small shifts on both species composition and $\mathrm{EQR}$ of phytoplankton values along the sampling period allow us to infer that this reservoir had very low nutrient input and external disturbances. On the other hand, there was a high abundance of high efficiency filter feeders in the sampling period. This situation can also be a factor related to the good quality of the water and ecosystem stability, as high-efficiency filtrators in zooplankton communities, more specifically cladocerans, play an important role on the top-down control of phytoplankton and algae blooms (An et al., 2012).

As observed by other authors (Caroni \& Irvine, 2010; Jeppesen et al., 2011), zooplankton provided a very complete image of alterations occurred in the ecosystem and its structure and functionality, in contrast to the information provided by the environmental and phytoplankton data in isolation.

\section{ACKNOWLEDGEMENTS}

Sara C. Antunes received a post doc grant (SFRH/BPD/109951/2015) from the Portuguese Foundation for Science and Technology (FCT). This research was partially supported by CIIMAR through the Strategic Funding UID/Multi/04423/2013 through national funds provided by FCT and European Regional Development Fund (ERDF), in the framework of the programme PT2020. This research was also funded and developed under Project $\mathrm{N}^{\circ}$ POCI-01-0145-FEDER-029368, co-financed by COMPETE 2020, Portugal 2020 and the European Union through the ERDF, and by FCT through national funds. The authors thank two anonymous reviewers who contributed to improve the manuscript.

\section{REFERENCES}

ABRANTES, N., S. C. ANTUNES, M. PEREIRA \& F. GONÇALVES. 2006. Seasonal succession of cladocerans and phytoplankton and their interactions in a shallow eutrophic lake (Lake Vela, Portugal). Acta Oecologica, 
29: 54-64. DOI: 10.1016/j.actao.2005.07.006 ADRIAN, R. \& T. M. FROST. 1993. Omnivory in cyclopoid copepods: comparisons of algae and invertebrates as food for three, differently sized species. Journal of Plankton Research, 15: 643-658. DOI: 10.1093/plankt/15.6.643

ALLEN, A. P., T. R. WHITTIER, P. R. KAUFMANN, R. J. O'CONNOR, R. M. HUGHES, R. S. STEMBERGER, S. S. DIXIT, R. O. BRINKHURST, A. T. HERLIHY \& S. G. PAULSEN. 1999. Concordance of taxonomic composition patterns across multiple lake assemblages: effects of scale, body size, and land use. Canadian Journal of Fisheries and Aquatic Sciences, 56: 2029-2040. DOI: 10. 1139/f99-139

ALONSO, M. 1996. Crustacea, Branchiopoda, Vol 7. Editorial CSIC-CSIC Press. Madrid, Espanha.

AMOROS, C. 1984. Crustacés cladocères. Societé Linnéenne. Lyon, França.

AN, X., Z. DU, J. ZHANG, Y. LI \& J. QI. 2012. Structure of the zooplankton community in Hulun Lake, China. Procedia Environmental Sciences, 13: 1099-1109. DOI: 10.1016/j. proenv.2012.01.103

APHA, AWWA \& WPCF. 1989. Standard methods for the examination of water and wastewater. 17th Edition. American Public Health Association, Washington, DC, USA.

AZEVÊDO, D., J. BARBOSA, W. GOMES, D. PORTO, J. MARQUES \& J. MOLOZZI. 2015. Diversity measures in macroinvertebrate and zooplankton communities related to the trophic status of subtropical reservoirs: contradictory or complementary responses? Ecological Indicators, 50: 135-149. DOI: 10.1016/j.ecolind.2014.10.010

BARNETT, A. \& B. E. BEISNER. 2007. Zooplankton biodiversity and lake trophic state: explanations invoking resource abundance and distribution. Ecology, 88: 1675-1686. DOI: 10.1890/06-1056.1

BARNETT, A. J., K. FINLAY \& B. E. BEISNER. 2007. Functional diversity of crustacean zooplankton communities: towards a trait-based classification. Freshwater Biology, 52: 796-813. DOI: 10.1111/j.1365-2427. 2007.01733.x
BELLINGER, E. G. \& D. C. SIGEE. 2015. Freshwater algae: identification and use as bioindicators. John Wiley \& Sons. UK.

BERN, L. 1990. Size-related discrimination of nutritive and inert particles by freshwater zooplankton. Journal of Plankton Research, 12: 1059-1067.

BERN, L. 1994. Particle selection over a broad size range by crustacean zooplankton. Freshwater Biology, 32: 105-112.

BORCARD, D., P. LEGENDRE \& P. DRAPEAU. 1992. Partialling out the spatial component of ecological variation. Ecology, 73: 1045-1055. DOI: $10.2307 / 1940179$

BOXSHALL, G. A. \& S. H. HALSEY. 2004. An introduction to copepod diversity. The Ray Society. London. UK.

BROOKS, J. L. \& S. I. DODSON. 1965. Predation, body size, and composition of plankton. Science, 150 (3692): 28-35. DOI: 10.1126/ science.150.3692.28

BROWER, J. E., J. H. ZAR \& C. VON ENDE. 1998. Field and laboratory methods for general ecology. Mass: WCB McGraw-Hill. Boston. USA.

CABECINHA, E., R. CORTES, J. A. CABRAL, T. FERREIRA, M. LOURENÇO \& M. Â. PARDAL. 2009a. Multi-scale approach using phytoplankton as a first step towards the definition of the ecological status of reservoirs. Ecological Indicators, 9: 240-255. DOI: 10.1016/j.ecolind.2008.04.006

CABECINHA, E., P. J. VAN DEN BRINK, J. A. CABRAL, R. CORTES, M. LOURENÇO \& M. Â. PARDAL. 2009b. Ecological relationships between phytoplankton communities and different spatial scales in European reservoirs: implications at catchment level monitoring programmes. Hydrobiologia, 628: 27-45. DOI: 10.1007/s10750-009-9731-y

CARLSON, R. E. 1977. A trophic state index for lakes. Limnology and Oceanography, 22: 361-369. DOI: 10.4319/1o.1977.22.2.0361

CARMAN, K. R. \& D. THISTLE. 1985 Microbial food partitioning by three species of benthic copepods. Marine Biology, 88: 143-148.

CARONI, R. \& K. IRVINE. 2010. The potential of zooplankton communities for ecological assessment of lakes: redundant concept or 
political oversight? Biology and Environment: Proceedings of the Royal Irish Academy, 110B: 35-53. https://www.jstor.org/stable/ 20799767

CASTRO, B. B., S. C. ANTUNES, R. PEREIRA, A. M. V. M. SOARES \& F. GONÇALVES. 2005. Rotifer community structure in three shallow lakes: seasonal fluctuations and explanatory factors. Hydrobiologia, 543: 221-232. DOI: 10.1007/s10750-004-7453-8

CATALAN, J., M. VENTURA, A. MUNNÉ \& L. GODÉ. 2003. Desenvolupament d'un index integral de qualitat ecologica i regionalitzacio ambiental dels sistemes lacustres de Catalunya [Development of an integral index on ecological quality and environmental regionalization of lake systems in Catalonia]. Agencia Catalana de l'Aigua. Generalitat de Catalunya, Departament de Medi Ambient i Habitatge. Barcelona. Spain.

CELEKLI, A. \& B. ÖZTÜRK. 2014. Determination of ecological status and ecological preferences of phytoplankton using multivariate approach in a Mediterranean reservoir. Hydrobiologia, 740: 115-135. DOI: 10.1007/ s10750-014-1948-8

CHEN, G., C. DALTON \& D. TAYLOR. 2010. Cladocera as indicators of trophic state in Irish lakes. Journal of Paleolimnology, 44: 465-481. DOI: 10.1007/s10933-010-9428-2

CZERNIAWSKI, R. \& J. DOMAGAŁA. 2010. Similarities in zooplankton community between River Drawa and its two tributaries (Polish part of River Odra). Hydrobiologia, 638: 137-149. DOI: 10.1007/s10750-0090036-y

DEMOTT, W. R. 1985. Relations between filter mesh-size, feeding mode, and capture efficiency for cladocerans feeding on ultrafine particles. Archiv für Hydrobiologie Beiheft Ergebnisse der Limnologie, 21: 125-134.

DEMOTT, W. R. \& W. C. KERFOOT. 1982. Competition among cladocerans: nature of the interaction between Bosmina and Daphnia. Ecology, 63: 1949-1966. DOI: 10.2307/ 1940132

GELLER, W. \& H. MÜLLER. 1981. The filtration apparatus of Cladocera: filter mesh-sizes and their implications on food selectivity. Oecolo- gia, 49: 316-321. DOI: 10.1007/BF00347591

GERALDES, A. M. \& M. -J. BOAVIDA. 2007. Zooplankton assemblages in two reservoirs: one subjected to accentuated water level fluctuations, the other with more stable water levels. Aquatic Ecology, 41: 273-284. DOI: 10.1007/s10452-006-9057-z

GLIWICZ, Z. M. 1977. Food size selection and seasonal succession of filter feeding zooplankton in an eutrophic lake. Ekologia Polska, 25: 179-225.

HARDING, J. P. \& W. A. SMITH. 1974. A key to the British freshwater cyclopoid and calanoid copepods: with ecological notes. Freshwater Biological Association Westmoreland. Iver. UK.

HABERMAN, J. \& M. HALDNA. 2014. Indices of zooplankton community as valuable tools in assessing the trophic state and water quality of eutrophic lakes: long term study of Lake Võrtsjärv. Journal of Limnology, 73: 61-71. DOI: 10.4081/jlimnol.2014.828

HERSCHY, R. W. 2012. Dams and reservoirs, role. In: Encyclopedia of Lakes and Reservoirs. L. Bengtsson, R. W. Herachy \& R. W. Fairbridge (eds.): 191-199. Springer. Canada.

HESSEN, D. O. 1985. Filtering structures and particle size selection in coexisting Cladocera. Oecologia, 66: 368-372.

HESSEN, D. O., B. A. FAAFENG, V. H. SMITH, V. BAKKESTUEN \& B. WALSENG. 2006. Extrinsic and intrinsic controls of zooplankton diversity in lakes. Ecology, 87: 433-443. DOI: 10.1890/05-0352

INAG. 2009. Critérios para a classificação do estado das massas de água superficiais - Rios e Albufeiras. I.P. Ministério do Ambiente, do Ordenamento do Território e do Desenvolvimento Regional. Instituto da Água, I.P. Portugal.

INAG, I. P. 2009b. Manual para a avaliação da qualidade biológica da água. Protocolo de amostragem e análise para o Fitoplâncton. Ministério do Ambiente, do Ordenamento do Território e do Desenvolvimento Regional. Instituto da Água, I.P. Portugal.

INAG. 2012. Plano de gestão da região hidrográfica do Cávado, ave e Leça. Relatório de base. Parte 2 - caracterização e diagnóstico da região hidrográfica. APA. 
Portugal.

JENSEN, T. C., I. DIMANTE-DEIMANTOVICA, A. K. SCHARTAU \& B. WALSENG. 2013. Cladocerans respond to differences in trophic state in deeper nutrient poor lakes from Southern Norway. Hydrobiologia, 715: 101-112. DOI: 10.1007/s10750-012-1413-5

JEPPESEN, E., P. NÕGES, T. A. DAVIDSON, J. HABERMAN, T. NÕGES, K. BLANK, T. L. LAURIDSEN, M. SØNDERGAARD, C. SAYER \& R. LAUGASTE. 2011. Zooplankton as indicators in lakes: a scientific-based plea for including zooplankton in the ecological quality assessment of lakes according to the European Water Framework Directive (WFD). Hydrobiologia, 676: 279-297. DOI: 10.1007/s10750-011-0831-0

KEHAYIAS, G., E. CHALKIA, S. CHALKIA, G. NISTIKAKIS, I. ZACHARIAS \& A. ZOTOS. 2008. Zooplankton dynamics in the upstream part of Stratos reservoir (Greece). Biologia, 63: 699-710. DOI: 10.2478/s11756008-0129-5

KRISTENSEN, P., M. SØNDERGAARD \& E. JEPPESEN. 1992. Resuspension in a shallow eutrophic lake. Hydrobiologia, 228: 101-109. DOI: $10.1007 / \mathrm{BF} 00006481$

LEE, S. -W., S. -J. HWANG, S. -B. LEE, H. -S. HWANG \& H. -C. SUNG. 2009. Landscape ecological approach to the relationships of land use patterns in watersheds to water quality characteristics. Landscape and Urban Planning, 92: 80-89. DOI: 10.1016/j.landurbplan. 2009.02.008

LI, X., H. YU \& C. MA. 2014. Zooplankton community structure in relation to environmental factors and ecological assessment of water quality in the Harbin Section of the Songhua River. Chinese Journal of Oceanology and Limnology, 32: 1344-1351. DOI: 10.1007/ s00343-014-3303-3

LORENZEN, C. J. 1967. Determination of chlorophyll and pheo-pigments: spectrophotometric equations. Limnology and Oceanography, 12: 343-346. DOI: 10.4319/1o.1967.12.2.0343

MARTINEZ-HARO, M., R. BEIRAS, J. BELLAS, R. CAPELA, J. P. COELHO, I. LOPES, M. MOREIRA-SANTOS, A. M. REIS-HENRIQUES, R. RIBEIRO \& M. M.
SANTOS. 2015. A review on the ecological quality status assessment in aquatic systems using community based indicators and ecotoxicological tools: what might be the added value of their combination? Ecological Indicators, 48: 8-16. DOI: 10.1016/j.ecolind. 2014.07.024

MCCARTNEY, M., C. SULLIVAN, M. C. ACREMAN \& D. MCALLISTER. 1999. Ecosystem impacts of large dams. International Union for Conservation of Nature, Gland, Switzerland, Centre for Ecology and Hydrology. Wallingford. UK.

MOLLES, M. C. \& J. F. CAHILL. 1999. Ecology: concepts and applications. WCB/McGrawHill Dubuque, IA.

MOSS, B., D. STEPHEN, C. ALVAREZ, E. BECARES, W. VAN DE BUND, S. E. COLLINGS, E. VAN DONK, E. DE EYTO, T. FELDMANN, C. FERNÁNDEZ-ALÁEZ, M. FERNÁNDEZ-ALÁEZ, R. J. M. FRANKEN, F. GARCÍA-CRIADO, E. M. GROSS, M. GYLLSTRÖM, L. -A. HANSSON, K. IRVINE, A. JÄRVALT, J. -P. JENSEN, E. JEPPESEN, T. KAIRESALO, R. KORNIJÓW, T. KRAUSE, H. KÜNNAP, A. LAAS, E. LILL, B. LORENS, H. LUUP, M. R. MIRACLE, P. NÕGES, T. NÕGES, M. NYKÄNEN, I. OTT, W. PECZULA, E. T. H. M. PEETERS, G. PHILLIPS, S. ROMO, V. RUSSEL, J. SALUJÕE, M. SCHEFFER, K. SIEWERTSEN, H. SMAL, C. TESCH, H. TIMM, L. TUVIKENE, I. TONNO, T. VIRRO, E. VICENTE \& D. WILSON. 2003. The determination of ecological status in shallow lakes - a tested system (ECOFRAME) for implementation of the European Water Framework Directive. Aquatic Conservation: Marine and Freshwater Ecosystems, 13: 507-549. DOI: 10.1002/aqc.592

NAVARRO, E., L. CAPUTO, R. MARCÉ, J. CAROL, L. BENEJAM, E. GARCÍABERTHOU \& J. ARMENGOL. 2009. Ecological classification of a set of Mediterranean reservoirs applying the EU Water Framework Directive: a reasonable compromise between science and management. Lake and Reservoir Management, 25: 364-376. DOI: $10.1080 / 07438140903238567$ 
NOGUEIRA, M. G. 2001. Zooplankton composition, dominance and abundance as indicators of environmental compartmentalization in Jurumirim Reservoir (Paranapanema River), São Paulo, Brazil. Hydrobiologia, 455: 1-18. DOI: 10.1023/A:1011946708757

O'BRIEN, W. J., M. BARFIELD, N. D. BETTEZ, G. M. GETTEL, A. E. HERSHEY, M. E. MCDONALD, M. C. MILLER, H. MOOERS, J. PASTOR \& C. RICHARDS. 2004. Physical, chemical, and biotic effects on arctic zooplankton communities and diversity. Limnology and Oceanography, 49: 1250-1261. DOI: 10.4319/ 10.2004.49.4_part_2.1250

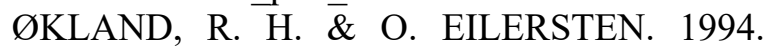 Canonical correspondence analysis with variation partitioning: some comments and an application. Journal of Vegetation Science, 5: 117-126. DOI: $10.2307 / 3235645$

PADISÁK, J., G. BORICS, G. FEHÉR, I. GRIGORSZKY, I. OLDAL, A. SCHMIDT \& Z. ZÁMBÓNÉ-DOMA. 2003. Dominant species, functional assemblages and frequency of equilibrium phases in late summer phytoplankton assemblages in Hungarian small shallow lakes. Hydrobiologia, 502: 157-168. DOI: 10.1023/B:HYDR.0000004278.10887.40

PAN, Y., A. HERLIHY, P. KAUFMANN, J. WIGINGTON, J. VAN SICKLE \& $\mathrm{T}$. MOSER. 2004. Linkages among land-use, water quality, physical habitat conditions and lotic diatom assemblages: a multi-spatial scale assessment. Hydrobiologia, 515: 59-73. DOI: 10.1023/B:HYDR.0000027318.11417.e7

PORTER, K. G., Y. S. FEIG \& E. F. VETTER. 1983. Morphology, flow regimes, and filter- ing rates of Daphnia, Ceriodaphnia, and Bosmina fed natural bacteria. Oecologia, 58: 156-163. DOI: 10.1007/BF00399211.

RIEPER, M. 1978. Bacteria as food for marine harpacticoid copepods. Marine Biology, 45: 337-345.

SANTOS, R., L. S. FERNANDES, M. PEREIRA, R. CORTES \& F. PACHECO. 2015. A framework model for investigating the export of phosphorus to surface waters in forested watersheds: implications to management. Science of the Total Environment, 536: 295-305. DOI: 10.1016/j.scitotenv.2015.07.058.

SCHINDLER, D. 1977. Evolution of phosphorus limitation in lakes. Science, 195: 260-262. DOI: $10.1126 /$ science. 195.4275 .260

SEIFRIED, S. \& J. DÜRBAUM. 2000. First clear case of carnivory in marine copepoda Harpacticoida. Journal of Natural History, 34: 1595-1618.

SMITH, V. H., G. D. TILMAN \& J. C. NEKOLA. 1999. Eutrophication: impacts of excess nutrient inputs on freshwater, marine, and terrestrial ecosystems. Environmental Pollution, 100: 179-196. DOI: 10.1016/S02697491(99)00091-3

TURNER, R. E. \& N. N. RABALAIS. 2003. Linking landscape and water quality in the Mississippi River basin for 200 years. BioScience, 53: 563-572. DOI: 10.1641/0006-3568 (2003)053[0563:LLAWQI]2.0.CO;2

WFD - Water Framework Directive. 2000. Directive 2000/60/EC of the European Parliament and of the Council establishing a framework for the Community action in the field of water policy.

Con el patrocinio de:

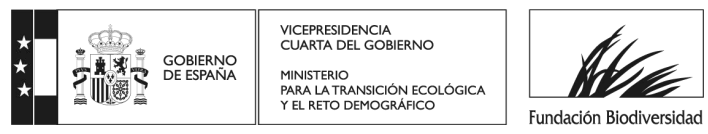

